\title{
Bioassaying the toxicity of tributyltin-(TBT)-polluted sediment to spat of the bivalve Scrobicularia plana
}

\author{
J. M. Ruiz*, G. W. Bryan**, P. E. Gibbs \\ Plymouth Marine Laboratory, Citadel Hill, Plymouth PL1 2PB, United Kingdom
}

\begin{abstract}
A solid-phase sediment toxicity bioassay with small spat ( 2 to $3 \mathrm{~mm}$ in length) of the estuarine bivalve Scrobicularia plana (da Costa) was run for $36 \mathrm{~d}$ in 1992: lethal and sublethal effects were investigated. While 2 negative control sediments allowed juvenile weight gain in excess of $140 \%$ of initial weight, a control sediment contaminated with non-tributyltin (TBT) compounds resulted in mortalities $>80 \%$ in $12 \mathrm{~d}$. A TBT-polluted sediment $\left(0.27 \mu \mathrm{g} \mathrm{Sn} \mathrm{g}{ }^{-1}\right.$ dry wt) did not produce any mortality or avoidance response, but both growth and burying activity of clams at the end of the trial were significantly reduced with respect to those of spat in control treatments. Although frozen storage of sediment samples renders this experiment somewhat inconclusive, results confirm suspicion of field TBT-sediment deleterious effects at $\sim 0.3 \mu \mathrm{g} \mathrm{Sn} \mathrm{g}^{-1} \mathrm{dry}$ wt. The environmental implications of findings are discussed in relation to the disappearance of $S$. plana populations throughout Atlantic Europe concurrent with TBT build-up in deposits; in addition, arguments are presented to emphasize the ecological relevance of sublethal stress affecting parameters such as the differential capability of benthic bivalves to avoid predation. Finally, the suitability of $S$. plana spat for widespread sediment toxicity bioassays is assessed.
\end{abstract}

KEY WORDS: Sediment toxicity bioassay TBT pollution - Bivalve juvenile Scrobicularia plana

\section{INTRODUCTION}

Over the last few years, a body of literature reporting on an unexplained decline of populations of the estuarine bivalve Scrobicularia plana (da Costa) has grown: the compilation by Essink et al. (1991) is a paramount reference on this decline for coasts from Germany to France, and wonders particularly about the observed non-winter disappearance of spat. A similar impoverishment of intertidal bivalve populations, notably $S$. plana, has also been recorded in the UK since the mid 1980s; in certain areas (e.g. Poole Harbour, Southampton Water) documented concurrent pollution by tributyltin (TBT) from antifouling paints was suspected of being the cause of this demise (Langston et al. 1987. 1990, Langston \& Burt 1991). A correlation between

\footnotetext{
- Address for correspondence: Institut Universitaire de Biologie Marine, 2, rue du Professeur Jolyet, F-33120 Arcachon, France

- Died on 17 September 1993; R.I.P.
}

TBT in sediments at $\sim 0.3 \mu \mathrm{g} \mathrm{Sn} \mathrm{g}^{-1}$ dry wt and disruption of the continuous structure of size-frequency histograms characteristic of healthy populations was established; it led to the hypothesis that spat are excluded from a long-lasting settlement by accumulation of toxic burdens through active deposit-feeding (Langston et al. 1990) (see also companion paper, Ruiz et al. 1994, this issue, for a more detailed introduction).

While it has been recently shown that environmentally realistic levels of TBT prevent a major proportion of the successive early stages (embryonic, larval) of Scrobicularia plana from undergoing normal development (Ruiz 1993), the companion paper proves that exposure of clam spat to low levels of dissolved TBT results in some adverse biological effects of particular relevance to the field situation described above. However, the holding of clams in artificial uncontaminated sand ignored a critical factor in the exposure of the juvenile stage of a deposit-feeding species, the sediment itself; this represents the primary source of food and, consequently, heavy metals (Luoma \& Bryan 
1982) and TBT (Langston \& Burt 1991). To overcome this deficiency, the solid-phase sediment toxicity bioassay described below was specifically designed to assess the suitability of field sediments for the development of S. plana juveniles. Of the approaches addressing sediment quality (see for instance Power \& Chapman 1992), assessment of overall toxicity was selected because it integrates the effects of real-world substrata. Although examination of selected biological end-points (survival, growth and burying activity) was the main concern of the test, chemical analyses were also conducted in an effort to identify the cause of detrimental effects.

\section{MATERIALS AND METHODS}

Bioassay sediments and chemical analyses. All 4 bioassay samples were collected from the top few $\mathrm{mm}$ of the surface sediment layer at mid-intertidal level of selected mudflats and kept frozen in polythene bags up to $5 \mathrm{~d}$ before the beginning of the test (Day -5). There were 2 negative (i.e. relatively uncontaminated) control sediments, collected at sites in the Torridge (North Devon, England, July 1991) and Guernica (Cantabrian coast of Spain, December 1991) estuaries; both localities support abundant and apparently healthy populations of Scrobicularia plana (Ruiz 1993). A sample from Bilbao estuary (Cantabrian coast of Spain, December 1991) was included in the bioassay as a sediment contaminated with compounds other than TBT which, despite sustaining a clam population (with juvenile recruits; Ruiz 1993), might not be totally innocuous to non-native individuals. Finally, sediments were collected at Cracknore (Southampton Water, England), a site at which superficial layers had been found to contain considerable levels of TBT (above $0.2 \mu \mathrm{g} \mathrm{Sn} \mathrm{g}^{-1}$ dry wt) but no $S$. plana spat since 1986 (at the latest). This mudflat is close to a dry dock facility and formerly supported a consistent clam population up to 1978; after this year, the $S$. plana population declined, the last remaining individuals (a few old specimens) contained around $3 \mu \mathrm{g} \mathrm{Sn} \mathrm{g}^{-1}$ dry wt (own data). Since highest organotin concentrations usually occur over the summer months (see for instance Langston et al. 1987) and this is the season of most active deposit-feeding in S. plana (Hughes 1969, Zwarts \& Wanink 1989), Cracknore TBT-contaminated sediments for bioassay were collected in July 1991.

Chemical extraction and analyses for 10 heavy metals and butyltins were performed on independently frozen aliquots of the fine portion of sediments $(<100 \mu \mathrm{m})$ as detailed by Bryan et al. (1985 and 1986, respectively) $)_{i}$ procedures for organotins included solvent rinsing with sodium hydroxide to separate the dibutyltin (DBT) from the TBT fraction. Using these methods trimethyltin might be present in the TBT fraction of natural sediments, although routine analyses of a small number of samples by GC-MS revealed that this was rarely the case. Tin was measured in a PerkinElmer 603 AA coupled with $76 \mathrm{~B}$ graphite furnace; detection limit was about $5 \mathrm{ng} \mathrm{Sn} \mathrm{g}^{-1}$ on a dry weight basis $\left(\left[\mathrm{TBT}^{+}\right]=2.5[\mathrm{Sn}]\right)$. The organic content of samples was also estimated from the loss in weight of dry $\left(85^{\circ} \mathrm{C}\right.$ ) aliquots heated at $400^{\circ} \mathrm{C}$ for $6 \mathrm{~h}$. Although no attempt was made to determine metallic content of interstitial water, it was deemed desirable to have an estimation of the concentration of selected heavy metals ( $\mathrm{Cd}, \mathrm{Cu}$ and $\mathrm{Zn}$ ) and TBT desorbed from sediments and leached into overlying water. To this end, volumes renewed in replicated containers on Day 18 were kept and pooled per treatment. The resulting $\sim 500 \mathrm{ml}$ (see Table 1) were divided and analysed as follows: (1) $400 \mathrm{ml}$ per treatment was acidified $(5 \mathrm{ml}$ concentrated $\mathrm{HCl} \mathrm{l}^{-1}$ ) and stored in the dark for TBT determination carried out as detailed in Bryan et al. (1986), rendering a detection limit of about $1 \mathrm{ng} \mathrm{Sn}^{-1}$; (2) heavy metal levels were directly analysed on small acidified volumes of the remaining sample in a Varian SpectrAA-20 flame $(\mathrm{Zn})$ or a Varian SpectrAA-300 Zeeman graphite furnace $(\mathrm{Cd}, \mathrm{Cu})$.

Bioassay specimens and experimental set-up. Bioassay individuals were collected from the Torridge estuary in February 1992 (for details see companion paper) because winter is the season in UK waters when small clams occur at a density high enough to permit collection of a sufficient number of specimens. Juveniles of Scrobicularia plana were distributed into 8 sets 140 clams each, 2 sets per sediment treatment) of identical size class composition (mean length $2.14 \pm 0.20 \mathrm{~mm})_{i}$ weight of initial sets and of size class individuals was also that estimated for the low-TBT experiment described in the companion paper, but initial burying time in sand is not pertinent for the present case.

On Day -5 , frozen sediment was taken to the constant temperature room $\left(15 \pm 1{ }^{\circ} \mathrm{C}, 12 \mathrm{~h}\right.$ illumination $\mathrm{d}^{-1}$ ) where the bioassay was conducted for $36 \mathrm{~d}$. On Day -4 , thawed sediments were sieved through a $500 \mu \mathrm{m}$ pore mesh to retain large masses and allowed to settle overnight in plastic beakers with $24 \pm 2 \%$ sea water. On Day -3 the overlying water was decanted off and filtered $(0.45 \mu \mathrm{m}) 24 \pm 2 \%$ sea water (hereafter referred to as FSW) added to settled sediments in beakers to make up a stock slurry $\sim 2: 1$ (sediment to FSW, by volume); aliquots $(5 \mathrm{ml})$ of these stock slurries were taken to estimate dry weight of sediment samples used in each bioassay. Experimental chambers were cylindrical Pyrex bowls $(9 \mathrm{~cm}$ diameter) which had been previously cleaned with detergent, acid and twice rinsed in distilled water; there were 4 bowls per 
sediment treatment. Stock slurry $(60 \mathrm{ml})$ was poured into each bowl and the volume brought to $240 \mathrm{ml}$ by adding $180 \mathrm{ml}$ FSW. Bowls were capped with a lid, and a plastic pipette tip connected to an airline was inserted through a hole in the cap so that a continuous but gentle flow of bubbles came out of the tip suspended $-1 \mathrm{~cm}$ below the water surface; the outflow of the air pump used was passed through 2 wash bottles (one empty, the second with distilled water) before it reached the tips to ensure air of high quality. Bowls were then left undisturbed until Day 0 when the water in the bowls was clear and sediments had settled and formed a layer $\sim 1 \mathrm{~cm}$ thick.

Initiation, procedure and termination of bioassay. There were duplicate clam sets (A and B) of each sediment, but 4 replicated bowls with sediment (A1, A2, B1 and B2) per treatment; this was designed to allow observation of juvenile burying activity into settled sediment by switching clams between bowls labelled with the same letter every sixth day as follows: on Day 0, 1 set of clams was introduced in each of 2 bowls per treatment (A1 and B1), and the number of juveniles failing to be totally buried was recorded at lapses of 2.5 min for the first $10 \mathrm{~min}$, then every $5 \mathrm{~min}$ up to $40 \mathrm{~min}$, and then at 10 min intervals to complete a $1 \mathrm{~h}$ observation; clams were then left undisturbed until Day 6. On this day, all individuals within a bowl (labelled A1 or B1) were sieved out of the sediment with a tea strainer, carefully observed under a microscope and dead clams (i.e. showing gaping valves and not reacting to gentle probing) removed for later identification and measurement; finally, live A1 and B 1 juveniles were introduced in bowls with settled sediment labelled A2 and B2, respectively, and burying time monitored as before for $1 \mathrm{~h}$. On Day 12, clams were dug out from sediment in bowls $\mathrm{A} 2$ and $\mathrm{B} 2$ and, after checking and removing dead ones, similarly shifted to bowls with settled sediment $\mathrm{A} 1$ and $\mathrm{B} 1$, respectively. Alternation of bowls containing juveniles and burying assay into settled sediment was repeated on Days 18,24, 30 and 36 (see Table 1 for a diagram of procedure). After a $1 \mathrm{~h}$ burying trial on Day 36, clam sets were dug out again, sized to the nearest $166 \mu \mathrm{m}$, blotted dry for $2.5 \mathrm{~h}$, weighed and frozen.

Partial exchange or total renewal of water was accomplished in each bowl every 3 or $6 \mathrm{~d}$ as follows (see also Table 1): on days when a bowl was going to receive clams (including bowls 1 on Day 0), one-third of the total volume (i.e. $80 \mathrm{ml}$ ) was siphoned out beforehand and fresh FSW $(80 \mathrm{ml})$ introduced carefully to produce minimal disturbance on settled sediment. On days when clams were going to be sieved out of a certain bowl and also in bowls 2 on Day 0, as much overlying water as possible was decanted beforehand to a graduated cylinder trying not to discard any sediment or clams; then, the same amount of FSW as collected in the cylinder was added to the sediment containing juveniles, plus distilled water to reach a total of $180 \mathrm{ml}$. The resulting slurry plus bivalves was sieved through the tea strainer to a transient bowl; the slurry (juveniles were retained in sieve) was then poured back to the original bowl and left undisturbed till the next sixth day when it received clams again. On Day 3 of the experiment and every sixth day thereafter, $80 \mathrm{ml}$ of overlying water was switched with equal volume of FSW as above only in bowls containing clams; $\mathrm{pH}$ and salinity were measured in the $160 \mathrm{ml}$ resulting from pooling per treatment the volumes siphoned out of bowls. When $80 \mathrm{ml}$ FSW was exchanged in bowls with or to receive clams, $\sim 2700000$ cells of the flagellate

Table 1. Diagram of procedure applied to sediment bioassay bowls. Asterisks indicate days when pH and salinity were measured in the $160 \mathrm{ml}(80 \mathrm{ml}$ from bowl $\mathrm{A} i+80 \mathrm{ml}$ from bowl $\mathrm{B} i$, where $i=1$ or 2 ) water switched per treatment. For further explanation see text

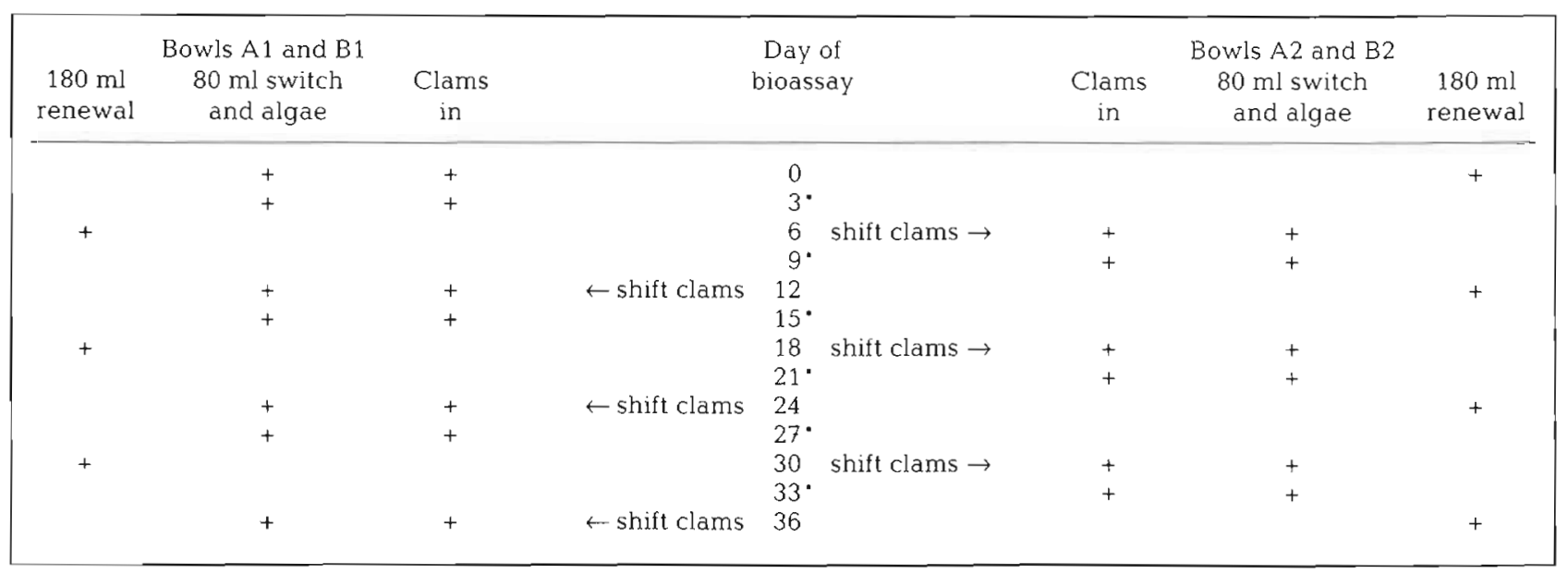


Isochrysis galbana (Parke) were also added as supplementary food to render a minimum final concentration of $\sim 15$ cells $\mu l^{-1}$ in each bowl.

\section{RESULTS}

\section{Sediment chemistry}

The concentrations of heavy metals as extracted with nitric acid from sediment aliquots are given in Table 2. Although some metals reach maxima in samples from Torridge (Co, Mn), Guernica (Ag, Ni) and Cracknore $(\mathrm{Cu}, \mathrm{Pb})$, levels of $\mathrm{Cd}, \mathrm{Cr}, \mathrm{Fe}$ and $\mathrm{Zn}$ are highest in those from Bilbao; higher concentrations of some metals in every sample are ascribable to their regional geological background and to site-specific contamination. The estimated dry weight of the sediment samples used in the bioassay, their organic content and their levels of organotin are also shown in Table 2. Dry weight of samples ranged from 31 to $43 \mathrm{~g}$, and the organic content from 3.5 to $5 \%$; butyltins were undetectable in sediments of both negative control sites (Torridge and Guernica), low in Bilbao and high in Cracknore deposits (i.e. $\mathrm{TBT}+\mathrm{DBT}=0.447 \mu \mathrm{g} \mathrm{Sn} \mathrm{g}^{-1}$ dry wt).

\section{Water chemistry and quality}

Concentrations of $\mathrm{Cd}, \mathrm{Cu}$ and $\mathrm{Zn}$ in supply and bioassay overlying waters renewed on Day 18 and pooled per treatment are given in Table 3; maximum levels were detected in water from Bilbao bowls for every metal, notably $\mathrm{Zn}\left(447 \mu \mathrm{g} \mathrm{l}^{-1}\right)$. TBT in overlying waters (Table 3) ranged from below detection limits in control samples to $36 \mathrm{ng} \mathrm{Sn} 1^{-1}$ in that of Cracknore; $\mathrm{Cd}, \mathrm{Cu}, \mathrm{Zn}$ and TBT $K_{\mathrm{p}}$ (sediment-water partition co- efficient) values are also given for each treatment. Values of $\mathrm{pH}$ and salinity in overlying waters as monitored throughout the bioassay (Table 3) remained consistent in every case at $\sim 8$ and $\sim 24 \%$, respectively.

\section{Acute toxicity of Bilbao sediments}

When the juveniles of Scrobicularia plana were first deposited on Bilbao sediments and observed for $1 \mathrm{~h}$ some clear avoidance behaviour was displayed. There were some individuals which probed the sediment with the foot but did not attempt to dig into it ${ }_{i}$ rather, they started crawling on the sediment surface, and some of them reached and climbed up walls of the vessel to drift away on the water surface by means of fine translucent byssal threads. However, after extensive probing, most of the juveniles had buried into the sediment by $10 \mathrm{~min}$. This burial was not permanent since a number of clams were observed to dig themselves out shortly afterwards; once unearthed, they crawled all over the sediment for long periods, stopping intermittently to probe the substratum. When bowls were checked on Day 3, only a few juveniles were observed to be unburied. The inhalant siphon of some buried individuals was fully extended, probably filtering the overlying waters; no siphon was seen to be cropping the sediment around the burrow entrance and, after close observation, no mark was found indicating that cropping (and therefore ingestion) of sediment had occurred at all. The sediment surface was smooth and untouched except for a number of tracks left by the clams when crawling throughout. No juvenile was found to be dead on Day 6, and when they were switched to bowls $A 2$ and $B 2$ reactions to sediments were less intensive than on Day 0. Many of the clams which managed to bury entered the substratum obliquely, and some did not stay beneath for long;

Table 2. Concentration ( $\mu \mathrm{g} \mathrm{g}^{-1}$ dry wt, Fe\%) of metals in bioassay sediments (the frozen fraction $<100 \mu$ m) as extracted with nitric acid; and concentration ( $\mu \mathrm{g} \mathrm{Sn} \mathrm{g}^{-1} \mathrm{dry}$ wt) of organotins, estimated dry wt of sediment samples used and their organic content. Total $=$ TBT + DBT. nd: not detectable

\begin{tabular}{|c|c|c|c|c|c|c|c|c|c|c|}
\hline Sediment & $\mathrm{Ag}$ & $\mathrm{Cd}$ & Co & $\mathrm{Cr}$ & $\mathrm{Cu}$ & $\mathrm{Fe}$ & $\mathrm{Mn}$ & $\mathrm{Ni}$ & $\mathrm{Pb}$ & $\mathrm{Zn}$ \\
\hline Torridge & 0.6 & 0.1 & 9 & 40 & 25 & 2.6 & 650 & 22 & 33 & 136 \\
\hline Guernica & 3.6 & 0.5 & 7.4 & 91 & 41 & 2.5 & 279 & 26 & 30 & 146 \\
\hline Cracknore & 0.7 & 1.1 & 7 & 50 & 189 & 2.6 & 173 & 16 & 186 & 494 \\
\hline Bilbao & 1.7 & 3.9 & 6.7 & 106 & 118 & 2.7 & 299 & 22 & 126 & 646 \\
\hline Sediment & & TBT & $\mathrm{DBT}$ & & Total & \multicolumn{2}{|c|}{$\% \mathrm{TBT}$} & \multicolumn{2}{|c|}{ Dry wt } & $\%$ organics \\
\hline Torridge & & nd & nd & & & & & \multicolumn{2}{|c|}{43.0} & 4.39 \\
\hline Guernica & & nd & nd & & & & & \multicolumn{2}{|c|}{31.1} & 5.05 \\
\hline Cracknore & & 0.269 & 0.177 & & 0.447 & & & \multicolumn{2}{|c|}{35.0} & 3.5 \\
\hline Bilbao & & 0.016 & 0.010 & & 0.026 & \multicolumn{2}{|c|}{62} & \multicolumn{2}{|c|}{41.1} & 3.69 \\
\hline
\end{tabular}


Table 3. Concentration of heavy metals $\left(\mu \mathrm{g}^{-1}\right.$ ) and TBT (ng Sn $\mathrm{l}^{-1}$ ) in supply and bioassay water (volumes renewed on Day 18 pooled per treatment). nd: not detectable $K_{\mathrm{p}}$ (sediment-water partition coefficient) in thousands except for Cd. Also given are mean $\pm \mathrm{SD}$ of $\mathrm{pH}$ and salinity in overiying waters as monitored in days throughout the test (see Table 1)

\begin{tabular}{|lcccccccccc|}
\hline Water & $\mathrm{Cd}$ & $K_{\mathrm{p}}$ & $\mathrm{Cu}$ & $K_{\mathrm{p}}$ & Zn & $K_{\mathrm{p}}$ & TBT & $K_{\mathrm{p}}$ & pH & Salinity (\%o) \\
\hline Supply & 1.7 & - & 7.8 & - & nd & - & nd & - & & \\
Torridge & 9.6 & 8 & 6.1 & 4.1 & 11 & 12 & nd & - & $8.2 \pm 0.1$ & $24.5 \pm 1.0$ \\
Guernica & 19 & 26 & 14 & 2.9 & 16 & 9.1 & nd & - & $8.0 \pm 0.1$ & $24.2 \pm 1.2$ \\
Cracknore & 6.0 & 182 & 16 & 12 & 70 & 7.1 & 36 & 7.5 & $7.9 \pm 0.2$ & $24.5 \pm 1.0$ \\
Bilbao & 22 & 176 & 30 & 4.0 & 447 & 1.4 & 14 & 1.1 & $8.2 \pm 0.1$ & $24.0 \pm 0.6$ \\
\hline
\end{tabular}

however, periods of crawling were brief and for shorter distances than on Day 0 . On Day 9, $-50 \%$ of clams were found unburied, and when checked on Day 12 heavy mortalities (mean $82.5 \pm 5 \%$ ) had occurred in both Bilbao vessels. Mortality increased slightly after that day, and only 6 clams survived in 1 of the 2 replicated Bilbao bowls until the end of the bioassay; no trace of cropping and ingestion of sediment was found in containers for the duration of the test.

\section{Chronic toxicity of Cracknore sediments}

Torridge, Guernica and Cracknore sediments were readily accepted as burying substrata by juvenile Scrobicularia plana: most clams had dug in by $2.5 \mathrm{~min}$ with apparent ease. Burial was permanent and only very few individuals were observed to be unearthed throughout the test. Many clams displayed siphon activity shortly after burying, sampling and cropping the sediment around the burrow entrance; dark particles of sediments could be seen being ingested through the white-translucent siphons. As a result of this feeding activity, all the sediment surface in bowls containing the 6 juvenile sets considered had been processed in a few days, presenting an uneven and finely granulated appearance; it also showed abundant distinct formations of sediment ejected through the exhalant siphon (i.e. pseudofaeces) and fecal pellets. All sediment bowls with clams showed this same aspect for the duration of the test. Growth of juvenile sets after 36 d exposure to bioassay sediments was cal- culated as detailed in the companion paper for the parallel low-TBT toxicity test: the blotted dry weight of clam sets at the conclusion of the bioassay (Table 4) was expressed as a percentage of the mean weight of initial sets (Table 4) after correcting for the individual weight (Table 1 in companion paper) of the very rare mortalities which occurred (Table 4). When transformed data were analysed by ANOVA and StudentNewman-Keuls test (SNK, $\alpha=0.05$; Table 5), clams in the Cracknore sediments were shown to have gained significantly less weight (mean 36\%) than those in either the Torridge or Guernica treatments (mean gain 196 and $140 \%$, respectively). The observed presence of new rings in the shells of most individuals (see Table 4 for total shell length gained by clam sets) also indicates clear growth which in some control juveniles reached $1.5 \mathrm{~mm}$ in length. Assuming that all clams in a given set grew at a constant and common rate throughout the experiment, the individual shell growth rate could be calculated to have been $\sim 12 \mu \mathrm{m} \mathrm{d}^{-1}$ in control treatments while only $\sim 4 \mu \mathrm{m} \mathrm{d}^{-1}$ in Cracknore sediments (Table 4).

Original data on the burying activity of each set of clams during the $1 \mathrm{~h}$ assay every sixth day were transformed using the formula described in the companion paper; the burying times calculated for each individual observation are plotted in Fig. 1. While mean burying time of individuals held in both control sediments was always less than $4 \mathrm{~min}$, burying time of Cracknoretreated clams exceeded that time from Day 24 onwards. ANOVA and the post hoc SNK test displayed no significant difference between mean burying time

Table 4. Scrobicularia plana. Number of survivors in each duplicated sediment treatment and growth parameters (mean \pm SD) of clam sets at conclusion of bioassay: total blotted dry weight, total shell length gained and estimated individual shell growth rate

\begin{tabular}{|c|c|c|c|c|c|}
\hline \multirow[t]{2}{*}{ Treatments } & \multicolumn{2}{|c|}{ No. of survivors } & \multirow{2}{*}{$\begin{array}{l}\text { Total weight } \\
\text { (mg) }\end{array}$} & \multirow{2}{*}{$\begin{array}{l}\text { Total shell gain } \\
\qquad(\mathrm{mm})\end{array}$} & \multirow{2}{*}{$\begin{array}{l}\text { Shell growth rate } \\
\left(\mu \mathrm{m} \text { juvenile } \mathrm{d}^{-1}\right.\end{array}$} \\
\hline & Dupl. A & Dupl. B & & & \\
\hline Initial & 40 & 40 & $15.25 \pm 0.05$ & - & - \\
\hline Torridge & 40 & 38 & $44.70 \pm 1.20$ & $17.58 \pm 1.25$ & $12.51 \pm 0.57$ \\
\hline Guernica & 40 & 40 & $36.55 \pm 4.15$ & $17.75 \pm 1.58$ & $12.33 \pm 1.10$ \\
\hline Cracknore & 40 & 39 & $20.60 \pm 0.90$ & $5.42 \pm 0.42$ & $3.81 \pm 0.34$ \\
\hline
\end{tabular}


Table 5. Scrobicularia plana. ANOVA of percentage weight gain and burying time of juvenile sets after exposure to sediments during bioassay. Variances of all 3 data sets had been shown to be homogeneous by Cochran's test: $C<C_{95}(3,1)$. ns: not significant, $p<0.05, \cdots p<0.01$

\begin{tabular}{|c|c|c|c|c|}
\hline Source & $\mathrm{df}$ & MS & $F$ & $\mathrm{p}$ \\
\hline \multicolumn{5}{|l|}{ Weight gain Day 36} \\
\hline Sediment & 2 & 13146 & \multirow[t]{3}{*}{24.3} & \multirow[t]{3}{*}{$0.014^{*}$} \\
\hline Error & 3 & 542 & & \\
\hline SNK: Torridge = Guernica $>$ Cracknore & & & & \\
\hline \multicolumn{5}{|l|}{ Burying time Day 0} \\
\hline Sediment & 2 & 1.20 & \multirow[t]{2}{*}{3.02} & \multirow[t]{2}{*}{$0.19 \mathrm{~ns}$} \\
\hline Error & 3 & 0.40 & & \\
\hline \multicolumn{5}{|l|}{ Burying time Day 36} \\
\hline Sediment & 2 & 3.49 & \multirow[t]{3}{*}{34} & \multirow[t]{3}{*}{$0.008^{\cdots}$} \\
\hline Error & 3 & 0.10 & & \\
\hline SNK: Cracknore $>$ Torridge $=$ Guernica & & & & \\
\hline
\end{tabular}

of clams in all 3 treatments on Day 0, but it showed that juveniles exposed to Cracknore sediments buried significantly slower on Day 36 than those kept in either negative control sediment (Table 5).

\section{DISCUSSION}

Frozen heavy metal polluted sediments from Bilbao were acutely toxic to juveniles from the Torridge Scrobicularia plana population, killing more than $80 \%$ of individuals in $12 \mathrm{~d}$. Sediments first induced some remarkable instances of avoidance behaviour (emergence, crawling, drifting), suggesting that clams would have moved into a sediment of a lesser toxicity had it been available (see McGreer 1979); later reduction in the refusal response may have resulted from either diminished condition and fatigue of individuals and/or from amelioration of toxic conditions in bowls through repeated renewal of the supernatant water. Frozen TBT-polluted sediments from Cracknore did not elicit any avoidance response or any mortality in S. plana juveniles, but they were chronically stressful in that Cracknore-exposed clams grew significantly less than juveniles in control treatments; in addition, after $36 \mathrm{~d}$ exposure, individuals buried more slowly into Cracknore sediments. than into control substrata. These results may be subject to criticism because the bioassay suffers 2 of the 4 limitations most sediment toxicity tests have: (1) disruption of sediment geochemistry and the kinetic activity of bedded contaminants through sampling, storage and handling, and (2) toxicological uncertainties (Lamberson et al. 1992).

As for the first point, collection of intertidal superficial sediments at low tide is possibly the least disturbing sampling method that can be applied, and handling as described above mimics to some extent resuspension of the most unstable and oxic sediment layers. However, storage procedure is likely to have affected the toxicity of some contaminants (see for instance Schuytema et al. 1989), but it was selected because freezing is the best possible way to store sediments for several months as required by bioassay characteristics; in addition, no storage technique totally respects integrity of field samples, and frozen sediments have been shown to be reasonably stable for their heavy metal (Thomson et al. 1980) and organotin (Quevauviller \& Donard 1990) content. It is therefore recognised that observations would need to be confirmed by repeated trials using freshly collected sediments.

As for the second caveat, in investigating the cause of toxicity of coastal sediments we first encounter the problem of determining the actual exposure levels of, perhaps, thousands of chemicals and, secondly, quantifying the route of exposure to select those phases of concern for a given biological species. Since sediments from the banks of the heavily industrialised Bilbao estuary have been characterised as considerably polluted by metallic and organic compounds (Ruiz 1993 and own data), contamination of Bilbao sediments used in bioassay with a myriad of potentially toxic substances is strongly suspected. On the other hand, there is neither evidence nor suspicion of Cracknore sediments being seriously polluted by chemical contamination other than TBT. Due to analytical constraints, only the concentrations of 10 heavy metals and butyltins were determined in sediment samples (Table 2), and of some metals and TBT in overlying waters of bioassay bowls (Table 3). Interstitial water was not considered because non-migrating depositfeeding bivalves do not interact with pore water as much as other groups (non-tubicolous amphipods, worms). Scrobicularia plana is primarily a deposit- 

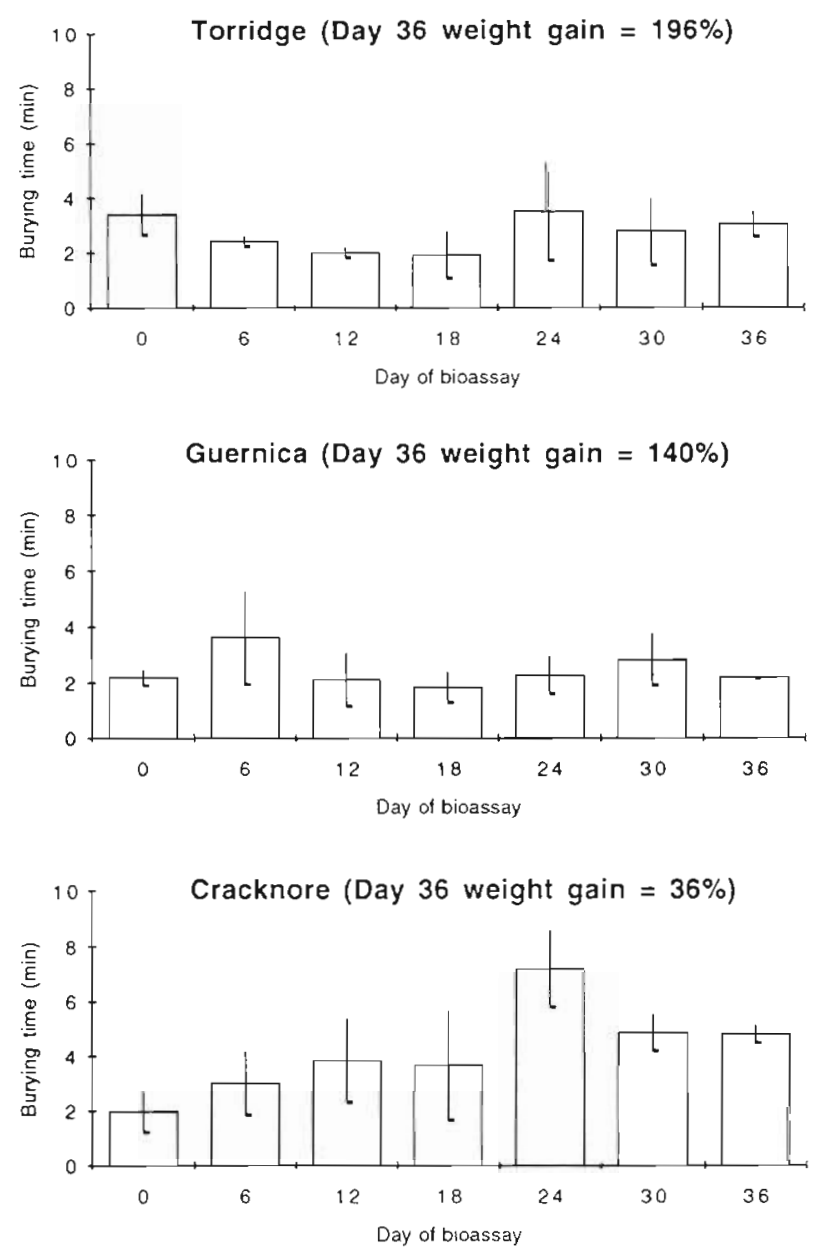

Fig. 1 Scrobicularia plana. Burying time (mean $\pm \mathrm{SD}$ ) of juveniles after exposure to negative control (Torridge and Guernica) and TBT-contaminated (Cracknore) sediments during bioassay

feeder in which tissue concentrations of heavy metals and TBT are largely controlled by the levels of these compounds in surface sediments and their partitioning between different sediment constituents such as humics, organic carbon and hydrous oxides of both $\mathrm{Fe}$ and Mn (Luoma \& Bryan 1982, Langston \& Burt 1991). Further, the feeding mode of $S$. plana accounts for the rarity of horizontal migrations (Hughes 1969), and this allows the walls of its relatively permanent burrows to be well ventilated and therefore oxidized; this may act as a partial barrier to remobilized metals (cf. Bryan 1985) which may not have sufficient time to equilibrate with pore water within burrows. In this respect, mass balance results indicated that uptake of hexachlorobenzene (HCB) by the gut from ingested solids was the single most important phase of exposure in the deposit-feeding clam Macoma nasuta (Conrad), accounting for 63 to $89 \%$ of $\mathrm{HCB}$ tissue residues (Boese et al. 1990); these authors concluded that the impor- tance of ingested solids to pollutant tissue residues increases for compounds with high $K_{\text {ow }}$ (octanol-water partition coefficient). Since TBT is rather hydrophobic ( $K_{\text {ow }}=5500$ in sea water of $25 \%$; Laughlin et al. 1986), it is likely that active ingestion of TBT-polluted Cracknore sediments enhanced organotin body burdens in juveniles and, consequently, constituted the main factor resulting in the toxic effects suffered by clams; in addition, the $36 \mathrm{ng} \mathrm{Sn} \mathrm{l}^{-1}$ of TBT in overlying waters (i.e. within the range reducing $S$. plana juvenile growth; see companion paper) surely contributed to observed results.

Since juveniles in Bilbao treatments did not ingest any substantial amount of sediment, dissolved toxicants must have resulted in observed lethal effects. However, whether concentrations detected in overlying waters (Table 3) totally explain heavy clam mortalities is dubious. The $12 \mathrm{~d} \mathrm{LC}_{50}$ (concentration killing $50 \%$ of the population considered) for juvenile (2 to $3 \mathrm{~mm}$ ) Scrobicularia plana held in water was reported to be $325 \mathrm{\mu g} \mathrm{l}^{-1}$ for $\mathrm{Cu}$ and $8000 \mathrm{\mu g} \mathrm{l}^{-1}$ for $\mathrm{Zn}$ (Bryan \& Gibbs 1983); toxicity of $\mathrm{Cu}$ and $\mathrm{Zn}$ to the related clam Abra tenuis (Montagu) was observed to be additive. When similar-sized $S$. plana spat from Mylor Creek (typical concentrations in sediment of $1117 \mu \mathrm{g} \mathrm{Cu} \mathrm{g}{ }^{-1}$ and $980 \mu \mathrm{g} \mathrm{Zn} \mathrm{g}^{-1}$ ) were exposed for $18 \mathrm{~d}$ to Mylor Creek and Restronguet Creek sediments $\left(-490 \mu \mathrm{g} \mathrm{Cu} \mathrm{g}{ }^{-1}\right.$ and $\left.-494 \mu g \mathrm{Zn} \mathrm{g}{ }^{-1}\right)$, substantial mortalities $(80 \%$ ) only occurred in Restronguet Creek treatments; levels in the common overlying water were $40 \mu \mathrm{g} \mathrm{Cu} \mathrm{l}^{-1}$ and $300 \mu \mathrm{g} \mathrm{Zn} \mathrm{l^{-1 }}$ (Bryan \& Gibbs 1983). Results of Mylor Creek, Restronguet Creek and Bilbao sediment tests constitute yet another example of how chemical analyses provide indications of the relative contamination among sites, but not a measure of their potential for deleterious effects (Long 1992). On the other hand, Akberali et al. (1981) showed that $500 \mu \mathrm{g}$ $\mathrm{l}^{-1}$ was the threshold level of dissolved $\mathrm{Zn}$ inducing siphonal withdrawal and valve closure in adult $S$. plana $\sim 4 \mathrm{~cm}$ long, but exposure did not result in significant mortalities during $14 \mathrm{~d}$; similarly, concentrations of $\mathrm{Cu}$ in the range 20 to $80 \mu \mathrm{g} \mathrm{l^{-1 }}$ have proved sublethally stressful in $30 \mathrm{~d}$ to juvenile clams (see companion paper). It can then be concluded that levels of dissolved $\mathrm{Zn}$ and $\mathrm{Cu}$ in bioassay bowls stressed the juveniles, but synergism with other metals, organometals (including TBT present at detectable levels) and other toxicants should be considered to account for the acute toxicity of Bilbao sediments. Interestingly, small $S$. plana spat were collected from a clam population in the mudflat of Bilbao concurrently with sediment samples for bioassay (Ruiz 1993); this fact constitutes the preliminary indication that the native population of $S$. plana in Bilbao is tolerant of local toxic conditions. Increased tolerance to $\mathrm{Cu}$ was reported for 
the S. plana population of Restronguet Creek (Bryan \& Gibbs 1983), where the indigenous Nereis diversicolor has been recently shown to have inherited tolerance to $\mathrm{Cu}$ and $\mathrm{Zn}$ (Hateley et al. 1989) as suggested by Bryan \& Hummerstone (1971). Further research on this peculiar S. plana population of Bilbao is clearly warranted, particularly considering the toxicological uncertainties raised by the use of frozen, stored sediments in the current study.

With respect to the other 2 possible shortcomings of sediment bioassays listed by Lamberson et al. (1992), i.e. (1) sensitivity to natural sediment features and laboratory conditions and (2) ecological relevance of test, they are not thought to apply to the present technique. Water quality was maintained within safe limits (Table 3), and all samples of fine superficial deposits were collected at mudflats containing recruiting populations of Scrobicularia plana, except at Cracknore; behaviour of juveniles in the Cracknore treatment clearly shows that deleterious effects cannot be due to natural unsuitability of sediments. In addition, given the $S$. plana pseudofaeces production and high organic content (Hughes 1969), it is thought that sediment organic matter (Table 2) supplemented by algal foodstuff was not a limiting factor for juvenile growth in any bowl. As for the ecological relevance of the selected end-points, it has already been extensively discussed (see companion paper), and their relation to bivalve population dynamics is explicit; further validation was conferred a priori by field data and, thus, bioassay results confirm the suspicion of sediment ecotoxicity to $S$. plana at TBT concentrations

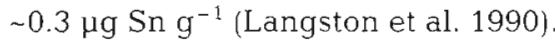

\section{Why Scrobicularia plana?}

An immediate question raised in view of the likely ecotoxicity of TBT is why other invertebrate species usually cohabiting TBT-affected estuarine habitats are not suffering a decline similar to that shown by Scrobicularia plana. A response is equally immediate: given the limited financial commitment, it is difficult to monitor a representative selection of the whole variety of species found along European coasts, and the general lack of documented reports does not necessarily mean absence of impact. The overall conclusion of Bryan \& Gibbs (1991), that untold consequences of releasing TBT are likely to have occurred through subtle toxicity to the reproduction and early life stages of marine organisms, must be accepted. For the sake of brevity, studies of molluscan species inhabiting mostly soft substrata provide important clues as to the extent of damage.

Thus, Minchin et al. (1987) found a strong correlation between declining populations of scallops and flame- shells and increased use of organotin net-dips on salmonid farms along the Irish coast, but their suspicion of detrimental effects of TBT on the reproduction and larval development of the bivalves could not be proved. Similarly, circumstantial evidence linking poor recruitment of Littorina littorea (L.) in estuaries of the English East Coast with substantial levels of dissolved TBT was shown (Matthiessen et al. 1991), but only very recently impaired periwinkle reproductive and larval hatching success have been found to be induced by 100 to $330 \mathrm{ng}$ TBT $\mathrm{l}^{-1}$ in laboratory experiments (P. Matthiessen pers. comm.). The fact that there are some characteristics of the life cycle of this gastropod which are shared by Scrobicularia plana (i.e longevity and planktonic veliger development) leads to the suggestion that, if $L$. Iittorea populations have not been harmed as much as those of the clam, it is probably because of their multiple periods of reproduction throughout the year. Since clams in Southern Europe recruit 2 or even 3 times a year (Bachelet 1981, Essink et al. 1991), this may also account for the absence of reports on affected $S$. plana populations in meridional areas well known to have been polluted by TBT (e.g. Arcachon Bay); successive larval and juvenile cohorts distributed from April to October and average autumnwinter conditions less adverse than in northern waters probably ameliorate effects of TBT and aid in maintenance of populations.

On the other hand, if no consistent decline of populations such as that reported for Scrobicularia plana by Essink et al. (1991) has been noticed in similar studies on other common sediment-dwelling bivalves [see Desprez et al. (1991) and Ducrotoy et al. (1991) for data about Macoma balthica (L.) and Cerastoderma edule (L.), respectively], an inverse correlation between environmental levels of TBT and bivalve recruitment has been observed for years in UK embayments (Langston et al. 1987, 1990). Thus, a conspicuous impoverishment of bivalve spat was found at sites in Southampton Water from the mid 1980s, and only some of the less polluted sites have shown a few signs of re-established recruitment in 1991-92 (W. J. Langston unpubl.); of a range of species surveyed [S. plana $M$. balthica, Mya arenaria (L.), Abra tenuis], only A. tenuis seems to have bred successfully in the presence of TBT. Since this probably monotelic clam lays its eggs (July-August in UK waters) in a mass within the sediment and, following direct development, miniature adults are hatched (Gibbs 1984), it is likely that its peculiar life cycle (lasting only 1 to 2 yr) has led to enhanced survival. The remainder of these bivalve species have planktonic larvae which are exposed to considerable risks (both natural and anthropogenic) during their development and, particularly, in nearbottom waters at the time of settlement. Nevertheless, 
for species reproducing only once a year in North Atlantic European waters, larval settling before water TBT concentrations reach seasonal maxima in mid-late summer (see for instance Langston et al. 1987) will usually allow spat to grow to 3 to $5 \mathrm{~mm}$ by the end of August (e.g. for $M$. balthica and $M$. arenaria in the Wadden Sea settlement occurs in spring; Günther 1991 and 1992, respectively). Burying capabilities afforded by 3 to $5 \mathrm{~mm}$ length guarantees a minimum depth refuge for overwintering. Since $S$. plana populations at northern latitudes concentrate spawning in August, early stages have a shorter time to grow before conditions become less favourable and, thus, it is quite possible that significant reductions induced by TBT on the larval (Ruiz 1993) and juvenile (see also Ruiz et al. 1994) growth rate are a factor of critical importance in the failure of recruits to prosper.

In addition, a multitude of factors, both physiological and ecological, may interact to result in the observed rarity of successful Scrobicularia plana recruitment. For instance, it is generally accepted that burial depth in bivalves is largely determined by length of siphons (Zwarts \& Wanink 1989) and shape of shell (Trueman 1983). It could be speculated that, in tidal flats where several bivalve species coexist sharing a common predator pressure, TBT (both dissolved and sedimentbound; see also Ruiz et al. 1994) will deprive S. plana spat of their natural strategies to avoid predation (i.e. ability to grow fast by secreting a thin shell and attainment of deep reburial rapidly). This would divert crab attention from equally shallow-buried but thickershelled Cerastoderma edule of a similar size (since they will be probably rejected in favour of a prey with less-resistant shell and, therefore, shorter handling time; see Boulding 1984) and also from similarly shelled spat of species such as Abra tenuis, Macoma balthica, Mya arenaria (which, for reasons described in the previous paragraph, will have reached a safer size and depth refuge). Predator foraging would therefore concentrate on the increasingly vulnerable $S$. plana recruits. This indirect effect of TBT is likely to be of high environmental relevance because decapad crustaceans appear relatively resistant to TBT (see review by Bryan \& Gibbs 1991) due to their fairly efficient ability to degrade it (Rice et al. 1989) and, as a result, crab activity in the field would not be substantially diminished by organotin pollution.

\section{The Scrobicularia plana spat sediment toxicity bioassay: suitable for routine use in Europe?}

Even though we do not intend to review current sediment-testing techniques and their reasoning, we wish to emphasize the potential of the present bioassay since there is an almost total absence of marine whole sediment bioassays using European autochthonous species (see Chapman et al. 1992). Scrobicularia plana is a coastal bivalve well distributed in both Atlantic and Mediterranean Europe, it is tolerant of a considerable salinity range and it accumulates pollutants mainly from solid phase sediments (through active deposit-feeding) but also from overlying waters; the usefulness of adult specimens to monitor organometallic and heavy metal pollution has been extensively proved (Langston \& Burt 1991 and Bryan \& Langston 1992, respectively). Its spat are relatively easy to collect in the field, to handle, to feed and to maintain in the laboratory with no major effort for both growth and toxicological studies (see Bachelet 1981, Bryan \& Gibbs 1983). Thus, it has been feasible to run the present experiment to test survival and growth in a way similar to that standardised for juvenile polychaetes (Pastorok \& Becker 1991). In addition, other sublethal indices reflecting fitness of spat of this and/or other intertidal or subtidal bivalve species, such as reburying activity (assessed as herein or otherwise, e.g. as with amphipods; see Swartz et al. 1985), are of high environmental relevance for early infaunal stages inhabiting the less stable layers of sediments (see also companion paper). Finally, bioaccumulation resulting from exposure to sediments may also be measurable.

Among the drawbacks this bioassay may present, 3 are considered foremost: (1) its inability to provide a way to elucidate possible mechanisms of toxicity; thus, the present procedure is one more plainly descriptive bioassay; (2) its restricted potential to become a third generation test (i.e. tests investigating toxicant effects on reproductive output); this disadvantage also applies to most current sediment tests and can apparently only be overcome by using short-lived species usually of a lesser importance for the local ecosystem; and (3) the limited availability of sufficient specimens to perform routine bioassays. Lacking a commercial source of Scrobicularia plana spat, individuals must be collected in the field; this restrains the working season, particularly in northern waters where the clam only reproduces once a year (Essink et al. 1991) and small spat can only be captured during a few months. The problem of mistaking juveniles of S. plana for those of other bivalve species which cohabit estuaries and are of similar external morphology (notably Abra tenuis; see Gibbs 1984) is considered to be minor for careful toxicologists with a basic training in bivalve taxonomy. Finally, although the use of different populations with differential sensitivity and pre-test history may render any intercalibration exercise impracticable, the current trend is towards finding the most appropriate bioassays for specific areas of concern by using indigenous species (Chapman \& Long 1983). Bearing in mind 
the likely ecotoxicity of TBT to S. plana populations in estuaries throughout the northeastern Atlantic and the persistence of butyltin in their deposits, it is concluded that the $S$. plana spat sediment bioassay certainly possesses the potential to become a very useful tool for assessment and regulatory purposes within Europe.

\section{CONCLUSIONS}

Frozen Bilbao sediments proved fatal to Scrobicularia plana juveniles unable to avoid them; it seems possible that the native clam population at Bilbao has developed a tolerance of local toxic conditions originated from heavy metal and, allegedly, other pollution. Sublethal effects of frozen Cracknore samples strongly suggest that field sediments polluted by TBT may act as a trap to $S$. plana secruits: sediments would allow prompt settlement of drifting juveniles (and, presumably, competent pediveliger larvae) which, by means of active deposit-feeding, may experience some growth; nevertheless, this would only be 20 to $25 \%$ (as weight gain) of the potential growth experienced in TBT-unaffected sediments. In the best case, incorporation to the reproductive stock of the population which in UK waters occurs by the second summer after settlement, when clams are $\sim 2 \mathrm{~cm}$ long (Hughes 1971) - will be delayed about 9 yr. In the most probable scenario, juvenile bivalves forced by their size to stay in shallow sediment layers will suffer the highest mortality rate because of predation, loss and exposure to extreme temperatures (Zwarts \& Wanink 1989). If washed out by wave action or current scour, debilitated spat would not rebury quickly, thus prolonging exposure and increasing risk of death (see also companion paper). This hypothesis is further supported by the observation of inert but live $S$. plana spat lying on the sediment surface during low tide in TBT-affected areas within Poole Harbour (N. D. Pope pers. comm.). Effects of sediment TBT will be worsened by concurrent exposure to increasing levels of dissolved TBT during the non-winter yachting season; joint action of other chemicals having similar gradients of contamination cannot be discarded.

Results of the bioassay constitute sound evidence of deleterious effects of TBT-polluted field sediments on local infauna, confirming concern about the environmental relevance of TBT accumulated in deposits (Langston et al. 1990, Waite et al. 1991, Dowson et al. 1992). Our observations may help to explain the widespread decline of Scrobicularia plana populations (Essink et al. 1991), addressing particularly the reported non-winter disappearance of clam spat. Superficial sediments containing levels of TBT of similar magnitude to those used here and shown to produce sublethal stress to juvenile $S$. plana have recently been reported for coastal areas throughout Atlantic Europe, Sado and Tejo estuaries in Portugal, Oléron Island and Arcachon Bay in France, Rhine and Scheldt estuaries in The Netherlands (Quevauviller \& Donard 1990), East Coast estuaries in the UK (Waite et al. 1991, Dowson et al. 1992), and, more specifically, in sites within Poole Harbour and Southampton Water where S. plana populations have been decimated (Langston et al. 1987, 1990, Langston \& Burt 1991, own data). It is therefore concluded that TBT in superficial sediments is likely to have greatly aided in preventing the successful settlement of $S$. plana spat in a number of European areas; in addition, the continued presence of moderate levels of deposit-bound TBT may render mudflats unsuitable for the development of juveniles of this and possibly other sediment-dwelling bivalves.

Acknowledgements. Thanks are due to G. R. Burt, P. L. Pascoe and N. D. Pope for analytical and field assistance, and to Dr W. J. Langston for comments on an early draft of the manuscript. J.M.R. received a FPI postgraduate grant from the DGICYT of the Spanish Ministry of Education and Science. This study was carried out in conjunction with investigations partly supported by the UK National Rivers Authority R \& D contract 105.

\section{LITERATURE CITED}

Akberali, H. B., Wong, T M., Trueman, E. R. (1981). Behavioural and siphonal tissue responses of Scrobicularia plana (Bivalvia) to zinc. Mar. environ. Res. 5: 251-264

Bachelet, G. (1981). Application de l'équation de von Bertalanffy a la croissance du bivalve Scrobicularia plana. Cah. Biol. mar. 22: 291-311

Boese, B. L., Lee, H., Specht, D. T., Randall, R. C., Winsor, M. H. (1990). Comparison of aqueous and solid-phase uptake for hexachlorobenzene in the Tellinid clam Macoma nasuta (Conrad): a mass balance approach. Environ. Toxicol. Chem. 9: 221-231

Boulding, E. G. (1984). Crab-resistant features of shells of burrowing bivalves: decreasing vulnerability by increasing handling time. J. exp. mar. Biol. Ecol. 76: 201-223

Bryan, G. W. (1985). Bioavailability and effects of heavy metals in marine deposits. In: Ketchum, B. H., Capuzzo, J. M., Burt, W. V., Duedall, I. W., Park, P. K., Kester, D. R. (eds.) Wastes in the ocean, Vol. 6, Nearshore waste disposal. Wiley-Interscience, New York, p. 41-79

Bryan, G. W., Gibbs, P. E. (1983). Heavy metals in the Fal estuary, Cornwall: a study of long-term contamination by mining waste and its effects on estuarine organisms. Occas. Publ. mar. biol. Ass. U.K. No. 2

Bryan, G. W. Gibbs, P. E. (1991). Impact of low concentrations of tributyltin (TBT) on marine organisms: a review. In: Newman, M. C., McIntosh, A. W. (eds.) Metal ecotoxicology: concepts and applications. Lewis Publishers, Inc., Ann Arbor, p. 323-361

Bryan, G. W., Gibbs, P. E., Hummerstone, L. G., Burt, G. R. (1986). The decline of the gastropod Nucella lapillus around South West England: evidence for the effect of tributyltin from antifouling paints. J. mar. biol. Ass. U.K. 66: 611-640 
Bryan, G. W., Hummerstone, L. G. (1971). Adaptation of the polychaete Nereis diversicolor to estuarine sediments containing high concentrations of heavy metals. 1 General observations and adaptation to copper. J. mar. biol. Ass. U.K. 51. 845-863

Bryan, G. W., Langston, W. J. (1992). Bioavailability, accumulation and effects of heavy metals in sediments with special reference to United Kingdom estuaries: a review. Environ. Poll. 76: 89-131

Bryan, G. W. Langston, W. J., Hummerstone, L. G., Burt, G. R. (1985). A guide to the assessment of heavy-metal contamination in estuaries using biological indicators. Occas. Publ. mar biol. Ass. U.K. No. 4

Chapman, P. M., Long, E. R. (1983). The use of bioassays as part of a comprehensive approach to marine pollution assessment. Mar. Pollut. Bull. 14: 81-84

Chapman, P. M., Swartz, R. C., Roddie, B., Phelps, H. L., van den Hurk, P., Butler, R. (1992). An international comparison of sediment toxicity tests in the North Sea. Mar. Ecol. Prog. Ser. 91: 253-264

Desprez, M., Bachelet, G., Beukema, J. J., Ducrotoy, J. P., Essink, K., Marchand, J., Michaelis, H., Robineau, B., Wilson, J. G. (1991). Dynamique des populations de Macoma balthica (L.) dans les estuaires du Nord-Ouest de l'Europe: premiere synthèse. In: Elliott, M., Ducrotoy, J. P. (eds.) Proceedings, ECSA 19 Symposium. Olsen \& Olsen, Fredensborg, p. 159-166

Dowson, P. H., Bubb, J. M., Lester, J. N. (1992). Organotin distribution in sediments and waters of selected East Coast estuaries in the U.K. Mar. Pollut. Bull. 24: 492-498

Ducrotoy, J. P., Rybarczyk, H., Souprayen, J., Bachelet, G., Beukema, J. J., Desprez, M., Dörjes, J., Essink, K., Guillou, J., Michaelis, H., Sylvand, B., Wilson, J. G., Elkaïm, B., Ibanez, F. (1991). A comparison of the population dynamics of the cockle (Cerastoderma edule, L.) in NorthWestern Europe. In: Elliott, M., Ducrotoy, J. P. (eds.) Proceedings, ECSA 19 Symposium. Olsen \& Olsen, Fredensborg, p. 173-184

Essink, K., Beukema, J. J., Coosen, J., Craeymeersch, J. A., Ducrotoy, J. P., Michaelis, H., Robineau, B. (1991). Population dynamics of the bivalve mollusc Scrobicularia plana da Costa: comparisons in time and space. In: Elliott, M., Ducrotoy, J. P. (eds.) Proceedings, ECSA 19 Symposium Olsen \& Olsen, Fredensborg, p. 167-172

Gibbs, P. E. (1984). The population cycle of the bivalve Abra tenuis and its mode of reproduction. J. mar. biol Ass. U.K. 64: $791-800$

Gunther, C.-P. (1991). Settlement of Macoma balthica on an intertidal sand flat in the Wadden Sea. Mar. Ecol. Prog Ser. 76: $73-79$

Gunther, C.-P. (1992). Settlement and recruitment of Mya arenaria in the Wadden Sea. J. exp. mar. Biol. Ecol. 159: $203-215$

Hateley, J. G., Grant, A., Jones, N. V. (1989). Heavy metal tolerance in estuarine populations of Nereis diversicolor. In: Ryland, J. S., Tyler, P. A. (eds.) Reproduction, genetics and distributions of marine organisms. Olsen \& Olsen, Fredensborg, p. 379-385

Hughes, R. N. (1969). A study of feeding in Scrobicularia plana. J. mar. biol. Ass. U.K. 49: 805-823

Hughes, R. N. (1971). Reproduction of Scrobicularia plana Da Costa (Pelecypoda: Semelidae) in North Wales. Veliger 14: $77-81$

Lamberson, J. O., DeWitt, T. H., Swartz, R. C. (1992). Assessment of sediment toxicity to marine benthos. In: Burton, G. A. (ed.) Sediment toxicity assessment. Lewis Publishers, Inc., Boca Raton, p. 183-211
Langston, W. J., Bryan, G. W., Burt, G. R., Gibbs, P. E. (1990). Assessing the impact of tin and TBT in estuaries and coastal regions. Funct. Ecol. 4: 433-443

Langston, W. J., Burt, G. R. (1991). Bioavailability and effects of sediment-bound TBT in deposit-feeding clams, Scrobic. ularia plana. Mar. environ. Res. 32: 61-77

Langston, W. J., Burt, G. R., Zhou, M. (1987). Tin and organotin in water, sediments and benthic organisms of Poole Harbour. Mar. Pollut. Bull. 18: 634-639

Laughlin, R. B. Jr, Guard, H. E., Coleman, W M. III (1986). Tributyltin in sea water: speciation and octanol-water partition coefficient. Environ. Sci. Technol. 20: 201-204

Long, E. R. (1992). Ranges in chemical concentrations in sediments associated with adverse biological effects. Mar. Pollut. Bull. 24: 38-45

Luoma, S. N., Bryan, G. W. (1982). A statistical study of environmental factors controlling concentrations of heavy metals in the burrowing bivalve Scrobicularia plana and the polychaete Nereis diversicolor. Estuar. coast. Shelf Sci. 15: 95-108

Matthiessen, P., Waldock, M. J., Thain, J. E., Milton, S., Scrope-Howe, S. (1991). Changes in periwinkle (Littorina littorea) populations following the ban on TBT-based antifoulings on small boats. Comm. Meet. int. Coun. Explor. Sea C.M.-ICES/E:5

McGreer, E. R. (1979). Sublethal effects of heavy metal contaminated sediments on the bivalve Macoma balthica (L). Mar. Pollut. Bull. 10: 259-262

Minchin, D., Duggan, C. B., King, W. (1987). Possible effects of organotins on scallop recruitment. Mar. Pollut. Bull. 18: $604-608$

Pastorok, R., Becker, S. (1991). Recommended guidelines for conducting laboratory bioassays on Puget Sound sediments. U.S. Environmental Protection Agency, Region 10, Office of Puget Sound, Seattle

Power, E. A., Chapman, P. M. (1992). Assessing sediment quality. In: Burton, G. A. (ed.) Sediment toxicity assessment. Lewis Publishers, Inc., Boca Raton, p. 1-18

Quevauviller, P., Donard, O. F. X. (1990). Variability of butyltin determination in water and sediment samples from European coastal environemnts. Appl. Organomet. Chem. 4: 353-367

Rice, S. D., Short, J. W., Stickle, W. B. (1989). Uptake and catabolism of tributyltin by blue crabs fed TBTcontaminated prey. Mar. environ. Res. 27: 137-145

Ruiz, J. M. (1993). Metallic pollution in estuaries, with special reference to the effects of tributyltin (TBT) and copper on the early life stages of Scrobicularia plana (Mollusca: Bivalvia). Ph.D. thesis, University of Plymouth

Ruiz, J. M., Bryan, G. W., Gibbs, P. E. (1994). Chronic toxicity of water tributyltin (TBT) and copper to spat of the bivalve Scrobicularia plana: ecological implications. Mar. Ecol. Prog. Ser. 113: 105-117

Schuytema, G. S., Nebeker, A. V., Griffis, W. L., Miller, C. E. (1989). Effects of freezing on toxicity of sediments contaminated with DDT and endrin. Environ. Toxicol. Chem. 8: $883-891$

Swartz, R. C., DeBen, W. A., Phillips, J. K., Lamberson, J. O., Cole, F. A. (1985). Phoxocephalid amphipod bioassay for marine sediment toxicity. In: Cardwell, R. D., Purdy, R., Bahner, R. C. (eds.) Aquatic toxicology and hazard assessment: 7 th symposium. ASTM STP 854, American Society for Testing and Materials, Philadelphia, p. 284-307

Thomson, E. A., Luoma, S. N., Cain, D. J., Johansson, C. (1980). The effects of sample storage on the extraction of $\mathrm{Cu}, \mathrm{Zn}, \mathrm{Fe}, \mathrm{Mn}$ and organic material from oxidized estuarine sediments. Wat. Air Soil Pollut. 14: 215-233 
Trueman, E. R. (1983). Locomotion in molluscs. In: Saleuddin, A. S. M., Wilbur, K. M. (eds.) The Mollusca, Vol. 4. Academic Press, New York, p, 155-198

Waite, M. E., Waldock, M. J., Thain, J. E., Smith, D. J., Milton, S. M. (1991). Reductions in TBT concentrations in U.K.

This article was submitted to the editor estuaries following legislation in 1986 and 1987. Mar. environ. Res. 32: 89-111

Zwarts, L., Wanink, J. (1989). Siphon size and burying depth in deposit- and suspension-feeding benthic bivalves. Mar. Biol. 100: 227-240

Manuscript first received: January 26, 1994

Revised version accepted: August 3, 1994 